\title{
KEWENANGAN DESA DALAM PENGELOLAAN HUTAN UNTUK MITIGASI PERUBAHAN IKLIM
}

\author{
THE AUTHORITY OF VILLAGE GOVERNMENT IN FOREST \\ MANAGEMENT TO MITIGATE CLIMATE CHANGE
}

\author{
Zunnuraeni \\ Dosen Fakultas Hukum Univesitas Mataram \\ Email : raenikun@gmail.com
}

\author{
Ahmad Zuhairi \\ Fakultas Hukum Universitas Mataram \\ Email : zhiro_0706@yahoo.co.id
}

Naskah diterima : 04/12/2018; direvisi : 15/04/2018; disetujui : 27/04/2018

\begin{abstract}
Purpose of this research is to know the authority of village government in forest management to mitigate climate change. Research method in this study is normative research with statute approach and conceptual approach. Based on result of the research can be concluded that forest around and in the village might managed by village under the right of village origin and the local authority of village. Forest that managed by the village can be a village forest that is a state village or traditional village that is a property right forest. One of the activity of forest management is environment service business that cover the activity to absorb and store carbon. Climate change mitigation based on REDD + basically is an activity that utilize forest to store and sink carbon in order to pressed the level of green house gasses emission.
\end{abstract}

\section{Keywords : Village; Forest; Authority; Mitigation; Climate Change}

\begin{abstract}
Abstrak
Penelitian ini bertujuan untuk mengetahui bagaimana kewenangan pemerintah desa dalam pengelolaan hutan untuk mitigasi perubahan iklim. Metode penelitian yang digunakan adalah penelitian hukum normatif dengan menggunakan pendekatan perundang-undangan dan pendekatan konseptual. Berdasarkan hasil penelitian disimpulkan bahwa hutan-hutan yang berada di sekitar dan dalam desa dapat dikelola oleh desa melalui kewenangan kewenangan berdasarkan hak asalusul dan kewenangan lokal berskala desa. Hutan yang dikelola oleh desa dapat berupa hutan desa yang merupakan hutan negara serta hutan adat yang merupakan hutan hak milik. Salah satu bentuk kegiatan pengelolaan hutan oleh desa adalah usaha jasa lingkungan yang meliputi di antaranya adalah kegiatan penyerapan dan atau penyimpanan karbon. Mitigasi perubahan iklim berdasarkan REDD + pada dasarnya berbentuk kegiatan yang memanfaatkan hutan untuk menyimpan dan menyerap karbon guna menekan tingkat emisi gas rumah kaca.
\end{abstract}

Kata Kunci : Desa; Hutan; Kewenangan, Mitigasi; Perubahan Iklim 


\section{PENDAHULUAN}

Pemanasan global yang mengakibatkan terjadinya perubahan iklim merupakan salah satu masalah lingkungan yang saat ini menjadi perhatian utama masyarakat internasional. Dampak negatif yang timbul akibat perubahan iklim memaksa negara-negara untuk duduk bersama dan menyepakati suatu komitmen guna mencegah peningkatan suhu bumi. Komitmen bersama pertama antara para pemimpin dunia berkenaan dengan upaya mitigasi perubahan iklim diadopsi dalam Konvensi Kerangka Perserikatan PBB Tentang Perubahan Iklim (United Nations Convention on Climate Change, (UNFCC)). Konvensi ini merupakan salah satu hasil dari KTT Bumi Tentang Lingkungan dan Pembangunan atau United Nations Conference on Environment and Development (UNCED) di Rio De Janeiro, Basil, pada bulan Junitahun 1992.

Daniel Murdiyarso menyebutkan bahwa terjadinya perubahan iklim adalah akibat kegiatan manusia. Berikut kutipan tulisan Daniel Murdiyarso mengenai penyebab terjadinya perubahan iklim:

"perubahan iklim adalah fenomena global yang dipicu oleh kegiatan manusia terutama yang berkaitan dengan penggunaan bahan bakar fosil (BBF) dan kegiatan alih guna lahan. Kegiatan tersebut dapat menghasilkan gas-gas yang makin lama makin banyak jumlahnya di atmosfer. Di antara gas-gas tersebut adalah karbondioksida (CO2), metana (CH4) dan nitrous oksida (N2O). Gasgas tersebut memiliki sifat seperti kaca yang meneruskan radiasi gelombang pendek atau cahaya matahari, tetapi menyerap dan memantulkan radiasai gelombang panjang atau radiasi balik yang dipancarkan Bumi yang bersifat panas sehingga suhu atmosfer bumi makin meningkat. Berada di bumi yang diliputi gas-gas tersebut bagaikan di dalam rumah kaca, yang selalu lebih panas dibandingkan suhu di luarnya. Oleh karena itu, gas-gas tersebut dinamakan gas rumah kaca (GRK) dan pengaruh yang ditimbulkannya dikenal dengan nama efek rumah kaca yang selanjutnya menimbulkan pemanasan global dan perubahan iklim".

Sejalan dengan pendapat Daniel Murdiyarso, laporan Interngovermental Panelon Climate Changes (IPCC) menyebutkan bahwa " setiap perubahan dalam iklim pada suatu selang waktu tertentu, diakibatkan oleh variasi alamiah atau karena aktivitas manusia (antropogenic)" (IPCC Report 2011). Bukti-bukti baru yang kuat menyatakan bahwa mayoritas pemanasan bumi yang diobservasi selama 50 tahun diakibatkan oleh aktivitas manusia. ${ }^{2}$

Sebagaimana disebutkan oleh Daniel Murdiyarso, penyebab utama perubahan iklim adalah penggunaan bahan bakar fosil dan kegiatan alih guna lahan. Penggunaan bahan bakar fosil terutama oleh negara-negara maju untuk kegiatan industrialisasi mereka. Adapaun negara-negara berkembang turut andil dalam peningkatan emisi gas rumah kaca melalui kegiatan alih guna lahan, dalam hal ini adalah pembukaan lahan-lahan hutan menjadi lahan perkebunan, lahan pertanian, maupun sebagai pemukiman. Hal ini sebagaimana dipaparkan oleh kementerian Kehutanan dalam laporannya sebagai berikut:

"Globally, emissions from land use,land use change and forestry (LULUFC) are huge. In the past 20 years, it has been estimated that the emission from LULUFC has reached $1.65 \mathrm{Gt}$ Carbon peryear. More

Daniel Murdiyarso, Protokol Kyoto,Implikasinya Bagi Negara Berkembang,Penerbit Buku Kompas, Jakarta, Mei, 2003, hlm. 1-2.

${ }^{2}$ Sebagaimana dikutip dari http://file.upi. edu/Direktori/FPMIPA/JUR. PEND. BIOLOGI/197212031999031-WAHYU SURAKUSUMAH/Adaptasi dan mitigasi.pdf, hlm. 3 (diakses pada 19 maret 2016 ). 
than $80 \%$ of this has been from developing countries, especiallythose which have large areasof tropical forest such as Brazil, Indonesia, Malaysia, Papua New Guinea, gabon, Costa Rica, Cameroon, republic of Congo and Democratic Republic of Congo. According to the 2007 IPCC Report, forest loss has reached an alarming 13 milions hectares per year, while a further 7.3 milions hectaresper year suffervarious degree of degradation."

Kegiatan pembukaan lahan hutan untuk dialihkan pada penggunaan lain menjadi penyumbang peningkatan gas rumah kaca. Sebuah laporan menyebutkan bahwa penggunaan lahan, perubahan penggunaan lahan dan kehutanan menyumbang sampai dengan $20 \%$ emisi gas rumah kaca penyebab pemanasan global. ${ }^{4}$ Pengalihan lahan hutan terutama terjadi pada hutan-hutan tropis. Indonesia merupakan salah satu dari 10 negara utama yang mengalami deforestasi hutan tropis.

Sebagai salah satu bentuk kegiatan manusia yang memberi pengaruh cukup signifikan terhadap peningkatan emisi gas rumah kaca,maka pengelolaan sektor kehutanan untuk mitigasi perubahan iklim menjadi sangat penting. Pengelolaan pada sektor kehutanan telah menjadi salah satu bagian dari mekanisme penurunan emisi gas rumah kaca. Pengelolaan hutan berupa reforestasi, aforestasi dan pencegahan deforestasi dimasukkan dalam mekanisme Protokol Kyoto. Bagi negara-negara maju kegiatan di bidang kehutanan berupa reforestasi, aforestasi dan pencegahan deforestasi merupakan kegiatan yang dilakukan secara domestik

\footnotetext{
${ }^{3}$ Kementerian Kehutanan Republik Indonesia, "Consolidation Report reducing Emission From deforestation and Forest Degrdation In Indonesia" 2008, hlm 16.

${ }^{4}$ International Timber Organization, Tropical Forrest and Climate Change, report of The International Expert Meeting on Addressing Climate Change through Sustainable Management of tropical Forest, yokohama, Japan, 30 April-2 may 2008, hlm 15.
}

atau melalui Joint Implementation. Adapun kegiatan di sektor kehutanan pada negara berkembang hanya dibatasi pada kegiatan aforestasi dan reforestasi melalui skema Mekanisme Pembangunan Bersih.

Adanya pembatasan pada jenis kegiatan sektor kehutanan melalui skema Mekanisme Pembangunan Bersih tidak menutup kemungkinan keikutsertaan negara berkembang dalam mitigasi perubahan iklim melalui kegiatan kehutanan yang lebih luas, hingga mencakup pada kegiatan mencegah deforestasi. Kegiatan pencegahan deforestasi oleh negara-negara berkembang dapat dilakukan melalui mekanisme REDD (Reducing Emissions From Deforestation and Forest Degradation atau Penurunan Emisi Melalui Deforestasi dan Degradasi Hutan. REDD pertamakali dibicarakan pada pertemuan negaranegara peserta UNFCC ke-11 tahun 2005 di Montreal. Pertemuan ini bertujuan untuk membahas mengenai penurunan emisi gas rumah kaca melalui kegiatan pencegahan deforestasi dan degradasi hutan,

Indonesia merupakan salah satu negara yang menyatakan sikap positif terhadap skema REDD. Komitmen Indonesia untuk turut dalam upaya penurunan emisi gas rumah kaca ditegaskan dengan menerbitkan Peraturan Presiden Nomor 2001 Tentang Tentang Rencana Aksi Penurunan Gas Rumah Kaca. Indonesia berkomitmen untuk menurunkan emisi gas rumah kaca hingga $26 \%$ pada tahun 2020.

Pemenuhan komitmen penurunan emisi gas rumah kaca memerlukan kerjasama dari berbagai pihak terkait, termasuk dalam hal ini adalah masyarakat lokal yang hidup didekat dan dalam hutan. Aturan hukum Indonesia memungkinkan keterlibatan masyarakat untuk turut terlibat dalam pengelolaan hutan melalui Program Pengelolaan Hutan Berbasis Masyarakat. Salah satu skema Pengelolaan Hutan Berbasis Masyarakat adalah hutan 
desa. Oleh karenaitu pengaturan mengenai hak akses masyarakat desa terhadap hutan berkenaan dengan mitigasi perubahan iklim menjadi penting. Artikel ini akan membahas mengenai Pengaturan hukum nasional Indonesia mengenai kewenangan pemerintah desa dalam pengelolaan hutan untuk mitigasi perubahan iklim.

Penelitian ini menggunakan metode penelitian hukum normatif. Terdapat beberapa metode pendekatan yang digunakan dalam penelitian ini, yaitu pendekatan Undang-undang (Statute Aprroach) dan pendekatan konseptual (Conceptual Approach). ${ }^{5}$ Pendekatan Undang-undang (Statute Approach) dilakukan dengan menelaah berbagai peraturan perudang-undangan yang terkait dengan perlindungan dan pengelolaan lingkungan hidup. Adapun pendekatan konseptual (Conceptual Approach) digunakan dengan beranjak pada pandangan-pandangan dan doktrindoktrin yang berkembang dalam ilmu hukum, khususnya dalam bidang ilmu hukum ketatanegaraan dan hukum lingkungan.

Penelitian hukum normatif adalah penelitian hukum kepustakaan. Penelitian ini hanya menggunakan bahan-bahan kepustakaan sebagai data penelitian, oleh karena itu maka pengumpulan data digunakan dengan melakukan penelusuran terhadap berbagai bahan kepustakaan yang tersedia di berbagai perpustakaan-perpustakaan, maupun penelusuran kepustakaan eletronik dengan menggunakan media internet. Bahan-bahan penelitian yang telah dikumpulkan selanjutnya di analisis dengan menggunakan metode analisis deskriptif kualitatif.

\section{PEMBAHASAN}

\section{Kewenangan Desa Berdasarkan UU Desa}

${ }^{5}$ Peter Mahmud Marzuki, Metode Penelitian Hukum, Jakarta, Kencana, 2005, hlm. 93.
Secara etimologi kata desa berasal dari bahasa sansekerta, deca yang berarti tanah air, tanah asal,atau tanah kelahiran. Berdasarkan sejarahnya, UU No 5 tahun 1979 tentang Pemerintahan Desa memposisikan desa berada di bawah kecamatan dan kedudukan desa diseragamkan di seluruh Negara Kesatuan Republik Indonesia. Hal ini menghambat tumbuhnya kreatifitas dan partisipasi masyarakat desa setempat karena mereka tidak dapat mengelola desa sesuai dengan kondisi budaya dan adat dari desa tersebut.

Pada era reformasi terjadi sejumlah perubahan dalam kehidupan ketatanegaraan Republik Indonesia, termasuk dalam hal pemerintahan daerah dan pemerintahan desa. UU No 22 tahun 1999 Tentang Pemerintahan Daerah merupakan produk perundang-undangan yang mengejawantahkan semangat otonomi yang luas pada daerah. UU ini kemudian diganti dengan UU No 32 tahun 2004 dan terakhir dengan UU No 23 tahun 2014.

Sebagaimana halnya pemerintahan daerah, pasca reformasi terjadi perubahan dalam pengaturan mengenai pemerintahan desa. Desa bukan lagi sekedar daerah administratif di bawah kecamatan, melainkan sebuah kesatuan masyarakat hukum yang memiliki kewenangan yang untuk mengatur dan mengurus rumah tangganya sendiri. Hal ini sebagaimana diatur dalam UU No 6 Tahun 2014 Tentang Desa.

Pengertian desa berdasarkan UU No 6 tahun 2014 adalah sebagai berikut :

"desa atau yang disebut dengan nama lain, selanjutnya disebut desa, adalah kesatuan masyarakat hukum yang memiliki batas-batas wilayah yang memiliki wewenang untuk mengatur dan mengurus kepentingan masyarakat setempat, berdasarkan prakarsa masyarakat, hak asal usul, dan/atau hak tradisional yang diakui dan dihormati dalam sistem 
pemerintahan Negara Kesatuan Republik Indonesia."

UU Desa disusun dengan semangat penerapan amanat konstitusi, yaitu pengaturan masyarakat hukum adat sesuai dengan ketentuan Pasal 18B ayat (2) dan Pasal 18 ayat (7) UUD NRI 1945, dengan konstruksi menggabungkan fungsi self-governing community dengan local self government, sehingga landasan konstitusional ini akan menjadi dasar yang kokoh bagi masa depan desa di Indonesia. Adapun tujuan pengaturan tentang desa sebagaimana di sebutkan dalam Penjelasan Umum UU Desa adalah:

1. Memberikan pengakuan dan penghormatan atas Desa yang sudah ada dengan keberagamannya sebelum dan sesudah terbentuknya NKRI.

2. Memberikan kejelasan status dan kepastian hukum atas Desa dalam sistem ketatanegaraanRepublikIndonesiademi mewujudkan keadilan bagi seluruh rakyat Indonesia.

3. Melestarikan dan memajukan adat, tradisi, dan budaya masyarakat Desa.

4. Mendorong prakarsa, gerakan, dan partisipasi masyarakat Desa untuk pengembangan potensi dan asset Desa guna kesejahteraan bersama.

5. Membentuk Pemerintahan Desa yang professional, efisien dan efektif, terbuka serta bertanggung jawab.

6. Meningkatkan pelayanan publik bagi warga masyarakat Desa guna mempercepat perwujudan kesejahteraan umum.

7. Meningkatkan ketahanan sosial budaya masyarakat Desa guna mewujudkan masyarakat Desa yang mampu memelihara kesatuan sosial sebagai bagian dari ketahanan nasional.

8. Memajukan perekonomian masyarakat Desa serta mengatasi kesenjangan pembangunan nasional; dan

9. Memperkuat masyarakat Desa sebagai subjek pembangunan.
Perubahan kedudukan Desa dari UU No.22/1999, UU No. 32/2004 dan UU No 6/2014 bertujuan agar Desa bukan lagi obyek pembangunan tetapi menjadi subyek pembangunan. Konstruksi pemerintahan desa yang dianut dalam UU Desa adalah konstruksi gabungan. ${ }^{6}$ Desa merupakan gabungan antara self governing community dan local self government dengan berdasarkan pada asas regognisi dan asas subsidiaritas. Kedudukan desa tersebut mempengaruhi kewenangankewenangan yang ada pada desa.

Kewenangan desa diatur dalam Pasal 18 sampai dengan Pasal 22 UU No 6 tahun 2014 Tentang Desa. Berikut akan dikutip ketentuan-ketentuan mengenai kewenangan desa.

\section{Pasal 18}

Kewenangan Desa meliputi kewenangan di bidang penyelenggaraan Pemerintahan Desa, pelaksanaan Pembangunan Desa, pembinaan kemasyarakatan Desa, dan pemberdayaan masyarakat Desa berdasarkan prakarsa masyarakat, hak asal usul, dan adat istiadat Desa.

\section{Penjelasan}

Yang dimaksud dengan "hak asal usul dan adat istiadat Desa" adalah hak yang masih hidup dan sesuai dengan perkembangan kehidupan masyarakat dan prinsip Negara Kesatuan Republik Indonesia.

\section{Pasal 19}

Kewenangan Desa meliputi:

a. Kewenangan berdasarkan hak asal usul;

b. Kewenangan lokal berskala Desa;

c. Kewenangan yang ditugaskan oleh PemerintahProvinsi, atauPemerintah Kabupaten/Kota; dan

6 Muhammad Yasin, dkk, Anotasi Undang-Undang No 6 Tahun 2014 Tentang Desa, Jakarta; PATTIRO, hlm. 43. 
d. kewenangan lain yang ditugaskan oleh Pemerintah, Pemerintah Provinsi, atau Pemerintah Kabupaten/Kota sesuai dengan ketentuan peraturan perundang-undangan.

\section{Penjelasan}

Huruf a: Yang dimaksud dengan "hak asal usul" adalah hak yang merupakan warisan yang masih hidup dan prakarsa Desa atau prakarsa masyarakat Desa sesuaidenganperkembangankehidupan masyarakat, antaralain sistem organisasi masyarakat adat, kelembagaan, pranata dan hukum adat, tanah kas Desa, serta kesepakatan dalam kehidupan masyarakat Desa.

Huruf b: Yang dimaksud dengan "kewenangan lokal berskala Desa"adalah kewenangan untuk mengatur dan mengurus kepentingan masyarakat Desa yang telah dijalankan oleh Desa atau mampu dan efektif dijalankan oleh Desa atau yang muncul karena perkembangan Desa dan prakarsa masyarakat Desa, antara lain tambatan perahu, pasar Desa, tempat pemandian umum, saluran irigasi, sanitasi lingkungan, pos pelayanan terpadu, sanggar seni dan belajar, serta perpustakaan Desa, embung Desa, dan jalan Desa.

Huruf c: Cukup Jelas

Huruf d: Cukup Jelas

\section{Pasal 20}

Pelaks a na $n$ kewe nanga berdasarkan hak asal usul dan kewenangan lokal berskala Desa sebagaimana dimaksud dalam Pasal 19 huruf a dan huruf $\mathrm{b}$ diatur dan diurus oleh Desa.

\section{Penjelasan}

Cukup Jelas

\section{Pasal 21}

Pelaksanaan kewenangan yang ditugaskan dan pelaksanaan kewenangan tugas lain dari Pemerintah,
Pemerintah Daerah Provinsi, atau Pemerintah Daerah Kabupaten/Kota sebagaimana dimaksud dalam Pasal 19 huruf c dan huruf d diurus oleh Desa.

\section{Penjelasan \\ Cukup Jelas}

\section{Pasal 22}

Ayat (1)

Penugasan dari Pemerintah dan/ atau Pemerintah Daerah kepada Desa meliputipenyelenggaraanPemerintahan Desa, pelaksanaan Pembangunan Desa, pembinaan kemasyarakatan Desa, dan pemberdayaan masyarakat Desa.

Ayat (2)

Penugasan sebagaimana dimaksud pada ayat (1) disertai biaya.

\section{Penjelasan}

Ayat (1): Cukup Jelas

Aturan lebih lanjut mengenai kewenangan desa terdapat dalam PP No 43 tahun 2014. Pada Pasal 43 ayat (1) PP No 43 tahun 2014 disebutkanbahwa hak asal-usul desa meliputi:

a. sistem organisasi masyarakat adat;

b. pembinaan kelembagaan masyarakat

c. pembinaan lembaga dan hukum adat;

d. pengelolaan tanah kas Desa; dan

e. pengembanganperanmasyarakatDesa

Adapun kewenangan lokal berskala

Desa terdiri atas kewenangan:

a. Pengelolaan tambatan perahu;

b. pengelolaan pasar Desa;

c.pengelolaantempatpemandianumum;

d. pengelolaan jaringan irigasi;

e. pengelolaan lingkungan permukiman masyarakat Desa;

f. pembinaan kesehatan masyarakat dan pengelolaan pos pelayanan terpadu;

g.pengembangandanpembinaansanggar seni dan belajar;

h. pengelolaan perpustakaan Desa dan taman bacaan;

i. pengelolaan embung Desa; 
j. pengelolaan air minum berskala Desa; dan

k. pembuatan jalan Desa antar permukiman ke wilayah pertanian

\section{Pengelolaan Hutan Desa Untuk Miti- gasi Perubahan Iklim}

Sebagian dari hutan tropis terbesar di dunia terdapat di Indonesia. Luas hutan tropis Indonesia menempati urutan ketiga setelah Brasil dan Republik Demokrasi Kongo (dulunya Zaire) dan hutan-hutan ini memiliki kekayaan hayati yang unik. ${ }^{7}$ Hutan-hutan tersebut banyak yang berada di sekitar desa-desa dan menjadi sumber pendapatan penduduk disekitarnya. Sekitar 23,81\% desa/kelurahan berlokasi di dalam dan di sekitar kawasan hutan. ${ }^{8}$ Adapun angka estimasi untuk masyarakat Indonesia yang bergantung pada hutan sangat bervariasi, dari 1,5-65 juta orangbergantung pada definisi mana yang digunakan dan agenda kebijakan mana yang diikuti. ${ }^{9}$ Oleh karena itu keterlibatan masyarakat lokal dalam pengelolaan hutan menjadi sangat penting. Memutuskan hubungan antara masyarakat dengan hutan tempat mereka bergantung akan memiliki dampak negatif pada aspek sosial dan ekonomi.

Tingginya laju deforestasi serta kemiskinan yang masih mencengkram masyarakat di sekitar dan dalam hutan mendoronglahirnya konseppemberdayaan masyarakat melalui Program Pengelolaan Hutan Berbasis Masyarakat (PHBM). Istilah PHBM sendiri sebenarnya bukan istilah asli yang berasal dari Indonesia. Istilah ini merupakan terjemahan dari Community based Forest Management yang dikembangkan dalam Program Ford Foundation, kemudian istilah

${ }^{7}$ FWI/GFW, 2001, Keadaan Hutan Indonesia, Bogor , Indonesia: Forest Watch Indonesia dan Washington D.C.: Global Forest Watch, hlm.1, https://www.wri.org/sites/ default/files/pdf/indoforest full id.pdf, (12/11/2017).

${ }^{8}$ BPS, Indonesia-Survey Kehutanan 2014, https://microdata.bps.go.id/mikrodata/index. php/catalog/723, (12/11/2017).

${ }^{9} \mathrm{FWI} / \mathrm{GFW}, \mathrm{Op}$.Cit.,hlm.3. kehutanan masyarakat atau Community Forest digunakan di Nepal, istilah lainnya adalah perhutanan sosial atau social forestry digunakan dalam program pemberdayaan masyarakat sekitar hutan di India. Indonesia hanya merangkum dan mengakomodir berbagai konsep dan istilah yang ada dalam pelaksanaan programnya. ${ }^{10}$

Istilah perhutanan sosial (social forest) dan hutan kemasyarakatan (community forest) memiliki berbagai definisi. Dalam sejumlah literatur kedua istilah tersebut digunakan secara bergantian. Sebagai contoh, FAO menyebutkan tidak ada definisi yang jelas mengenai perhutanan sosial sehingga istilah tersebut dapat digunakan dalam cara yang sama dengan hutan masyarakat yakni "setiap keadaan yang melibatkan penduduk setempat dalam sebuah aktifitas kehutanan". Adapun bagi penulis lain seperti Sands, menyebutkan bahwa perhutanan sosial mencakup konsep yang lebih luas daripada hutan masyarakat. Ia mengkonsep perhutanan sosial sebagai semua interaksi manusia dengan hutan yang juga mencakup hutan kemasyarakatan sebagaimana didefinisikan oleh FAO. Sebaliknya, bagi Wiersum perhutanan sosial merupakan konsep yang lebih sempit dari konsep FAO maupun konsep Sands. ${ }^{11}$ Dengan demikian tidak ada konsensus mengenai definisi perhutanan sosial maupun hutan kemasyarakatan. Perbedaan cara pandang maupun tujuan dalam mengkonsep Pengelolaan hutan berbasis masyarakat berakibat pada terdapatnya berbagai istilah dan definisi. Namun demikian, semua istilah tersebut muncul sebagai reaksi terhadap pendekatan tradisional yang

10 Rahmina, Pilihan Skema Pengelolaan Hutan Berbasis Masyarakat Dalam MItigasi Perubahan Iklim, Jakarta : GIZ dan FORCLIME, Juli 2012, hlm. 3.

11 Myrna Asnawati Safitri, Forest Tenure in Indonesia, The Socio Legal Challenges of Securing Communities's Rights, Doctoral Thesis, Faculty of Law, Leiden University, 2010, hlm. 49, https://openaccess.leidenuniv.nl/handle/1887/16242, (12/11/2017). 
ilmu pengetahuan dan kebijakan di bidang kehutanan yang cenderung mengabaikan dimensi manusia. ${ }^{12}$

Kerangka peraturan perundangundangan di Indonesia untuk sektor kehutanan diawali UU No 5 Tahun 1967 Tentang Ketentuan Pokok Kehutanan yang berlaku hingga tahun 1999, kemudian dicabut dan diganti dengan UU No 41 Tahun 1999 sebagaimana telah diubah dengan UU No 19 Tahun 2004 Tentang Penetapan PERPU No 1 Tahun 2004 Tentang Perubahan Atas UU No 41 Tahun 1999 tentang Kehutanan menjadi UU. Selain itu terdapat UU No 5 Tahun 1990 Tentang Konservasi Sumber Daya Alam dan Ekosistem serta peraturan pelaksana di bawahnya yang merincikan pengelolaan kawasan hutan sesuai dengan fungsi dan statusnya. ${ }^{13}$

Adapun pengelolaan hutan oleh dan atau bersama masyarakat sebelumnya diatur dalam serangkaian Peraturan Menteri Kehutanan, hingga ditentukan dalam Peraturan Pemerintah No 6/2007 Jo PP No 3 Tahun 2008 Tentang Tata Hutan dan Perencanaan Hutan, serta Pemanfaatan Hutan. Pengelolaan Hutan oleh Masyarakat yang diamanatkan dalam PP ini adalah dalam bentuk pemberdayaan masyarakat setempat, yaitu Hutan Desa, Hutan Kemasyarakatan dan Hutan Kemitraan. ${ }^{14}$

Hutan desa merupakan salah satu dari sejumlah skema pengelolaan hutan berbasis masyarakat yang ada di Indonesia. Mengacu pada penjelasan Pasal 5 UU No 41 Tahun 1999 Tentang Kehutanan, hutan desa adalah hutan negara yang berada di dalam wilayah suatu desa, dimanfaatkan oleh desa, untuk kesejahteraan masyarakat desa tersebut. Selanjutnya, di dalam PP No 6/2007 Tentang Tata Hutan dan Penyusunan Rencana Pengelolaan Hutan, Hutan Desa didefinisikan sebagai

\footnotetext{
${ }^{12}$ Ibid.

13 Rahmina, Loc.Cit

${ }^{14}$ Ibid.
}

hutan negara yang belum dibebani izin atau hak yang dikelola oleh desa untuk kesejahteraan masyarakat desa. Prinsip dasar dari hutan desa adalah membuka akses bagi desa-desa tertentu, tepatnya desa hutan terhadap hutan-hutan yang masuk wilayahnya. ${ }^{15}$ Model pengelolaan hutan desa dapat dilakukan pada kawasan hutan lindung dan hutan produksi dengan jangka waktu pengelolaan selama 35 tahun dan dapat diperpanjang berdasarkan evaluasi yang dilakukan paling lama setiap 5 tahun. Kebijakan mengenai hutan desa diatur dalam Peraturan Menteri Kehutanan Republik Indonesia P.89/ Menhut-II/2014. ${ }^{16}$

Salah satu kegiatan yang dapat dilaksanakan pada kawasan hutan desa adalah mitigasi perubahan iklim dalam skema REDD. Ruang lingkup REDD pada dasarnya mencakup kegiatan penurunan emisi gas rumah kaca pada sektor kehutanan. Adapun pengertian dan ruang lingkup REDD secara lebih detail berikut akan dipaparkan sebagai berikut:

Kepanjangan REDD dalam perdebatan di UNFCCC tidak selalu konsisten. Ia bisa kepanjangan dari pengurangan emisi dari deforestasi dan degradasi hutan di negara berkembang/Reducing Emissions from Deforestation and forest Degradation in developing countries atau kepanjangan dari Pengurangan emisi dari deforestasi di negara berkembang/Reducing Emissions from Deforestation in developing Countries. Kepanjangan REDD yang pertama itu merupakan istilah yang diperkenalkan oleh Indonesia pada COP 13, Desember 2007, diBali. Definisi resmi Indonesia tentang REDD adalah semua upaya pengelolaan hutan dalam rangka pencegahan dan atau pengurangan penurunan kuantitas

${ }^{15}$ Agus Budhi Prasetyo, Serba-Serbu Hutan Desa (HD), hlm. 1.

${ }^{16}$ Subekti Rahayu, dkk, Pemantauan dan Evaluasi Pengelolaan Hutan Desa Berbasis Masyarakat, Buku Pedoman, Bogor : World Agroforestry Centre (ICRAF), 2016, hlm. 1. 
tutupan hutan dan stok karbon yang dilakukan melalui berbagai kegiatan untuk mendukung pembangunan nasional yang berkelanjutan. ${ }^{17}$

Pada prinsipnya konsep REDD + mengacu pada dua aspek kegiatan, yaitu:

1. Pengembangan mekanisme memberi imbalan pada negara berkembang yang mengurangi emisi dari deforestasi dan degradasi hutan, konservasi, SFM, aforestasi dan reforestasi;

2. Kegiatan persiapan yang membantu negara-negara untuk mulai berpartisipasi dalam mekanisme $\mathrm{REDD}+.{ }^{18}$

Isu utama lain dari ReDD + adalah benefit sharing yaitu bagaimana menciptakan skema pembagian manfaat, ${ }^{19}$ terutama dalam hal ini adalah subyek penerima benefit. ${ }^{20}$ Berkenaan dengan subyek penerima benefit atau keuntungan, Keberadaan komunitas adat/lokal yang sejak lama hidup dan bergantung pada hutan harus dilibatkan. Banyak kelompok indigenous peoples seperti AMAN dari Indonesia, UN Permanent Forum on Indigenous Peoples, Aliansi Indigenous Peoples dari Amazon menekankan bahwa kehadiran mereka menjadi kunci keberhasilan proyek REDD. Sejumlah perkembangan dalam perdebatan COP menunjukkan respons terhadap eksistensi indigenous peoples sebagai subyek yang harus dipertimbangkan dalam berbagai isu seputar REDD, antara lain implementasi dan pembagian benefit. Namun, belum

${ }^{17}$ Mumu Muhajir dan Myrna A Safitri, "REDD di Indonesia Kebijakan Pemerintah dan Kerentanan Masyarakat" dalam Mumu Muhajir (ed), REDD di Indonesia kemana Akan Melangkah, Studi Tentang Kebijakan Pemerintah dan Kerentanan Masyarakat, Jakarta :HuMa, 2010, hlm. 10-11.

${ }_{18}$ Nurtjahjawilasa, dkk, Modul Konsep REDD + dan Implementasinya, Jakarta :The Nature Conservancy Program Terestrial Indonesia, 2013, hlm 13.

19 Ibid.

20 Bernadius Stenni, "Perubahan Iklim, REDD dan Perdebatan Hak: Dari Bali sampai Kopenhagen, dalam Mumu Muhajir (ed), Op.Cit. hlm. 84. ada proposal yang tegas mengenai perimbangan pembagian keuntungan. ${ }^{21}$

Pemegang ijin pengelola hutan desa adalah suatu lembaga pengelola yang dibentuk melalui Peraturan Desa (Perdes). Ijin pengelolaan dapat berupa Ijin Usaha Pemanfaatan Kawasan (IUPK), Ijin Usaha Pemanfaatan Jasa Lingkungan (IUPJL), Ijin Usaha Pemanfaatan Hasil Hutan Bukan Kayu (IUPHHBK), Ijin Pemanfaatan Hasil Hutan Bukan Kayu (IPHHK). Ijin usaha Pemanfaatan Hasil Hutan Kayu (IUPHHK) dan Ijin Pemanfaatan Hasil Hutan Kayu (IPHHK) diperbolehkan pada hutan desa yang terletak di kawasan hutan produksi. ${ }^{22}$

Pengelolaan hutan desa untuk mitigasi perubahan iklim dapat dilakukan dengan menggunakan Izin Usaha Pemanfaatan Jasa Lingkungan. Pada Pasal 2 Peraturan Menteri Kehutanan Republik Nomor :P.36/Menhut-II/2009

Tentang

Tatacara Perizinan Usaha Pemanfaatan Penyerapan Dan/Atau Penyimpanan Karbon Pada Hutan Produksi dan Hutan Lindung disebutkan bahwa : "Usaha pemanfaatan Penyerapan Karbon dan/ atau Penyimpanan Karbon (UP RAPKARBON dan/atau UP PAN-KARBON) merupakan salah satu jenis usaha pemanfaatan jasa lingkungan pada hutan produksi dan hutan lindung. Lebih lanjut dalam Pasal 5 disebutkan bahwa Izin usaha pemanfaatan hutan kemasyarakatan, dan pengelola hutan desa dapat mengajukan IUP RAP-KARBON dan/atau IUP PANKARBON.

Aturan lain terkait dengan kegiatan dalam hutan desa tercantum dalam Peraturan Menteri Kehutanan Republik Indonesia Nomor : P.89/MenhutII/2014 Tentang Hutan Desa. Pasal 25 Permenhut Nomor : P.89/Menhut-II/2014 menyebutkan :

Pemanfaatan kawasan pada Hutan Desa dapat dilakukan pada :

\footnotetext{
${ }^{21}$ Ibid.

${ }_{22}^{2}$ Ibid.
} 
a. hutan lindung untuk memanfaatkan kawasan, jasa lingkungan, pemungutan hasil hutan bukan kayu;

b. hutan produksi berhak untuk memanfaatkan kawasan, jasa lingkungan, pemanfaatan hasil hutan kayu dan bukan kayu, pemungutan hasil hutan kayu dan bukan kayu.

Lebih lanjut dalam Pasal 27 diatur mengenai kegiatan yang merupakan pemanfaatan jasa lingkungan pada hutan lindung, yaitu :

a. Pemanfaatan jasa aliran air;

b. Pemanfaatan air;

c. Wisata alam;

d. Perlindungan keanekaragaman hayati;

e. Penyelamatan dan perlindungan lingkungan; atau

f. Penyerapan dan/atau penyimpanan karbon.

Penyerapan dan/atau penyimpanan karbon merupan kegiatan yang berkaitan dengan mitigasi perubahan iklim. Melalui penyerapan dan/atau penyerapan karbon, tingkat emisi gas rumah kaca yang menjadi penyebab perubahan iklim dapat diturunkan. Adapun kegiatan usaha pemanfaatan penyerapan karbon pada hutan lindung meliputi sebagai berikut :

a. Penanaman dan pemeliharan dari bagian kegiatan izin usaha pemanfaatan kawasan hutan atau izin usaha pemanfaatan hutan kemasyarakatan dan hutan desa yaitu penyiapan lahan, pembibitan, penanaman, pemeliharaan, pemanenan dan pemasaran sesuai dengan sistem silvikultur yang ditetapkanpadaseluruharealataubagian hutan atau blok hutan.

b. Penanaman dan pemeliharaan sampai daur tanaman pada seluruh areal atau bagian hutan atau blok hutan pada izin usaha pemanfaatan kawasan hutan atau izin usaha pemanfaatan hutan kemasyarakatan dan hutan desa. c. Peningkatan produktivitas melalui peningkatan riap tegakan dengan penerapan silvi kultur. ${ }^{23}$

Berkenaan dengan kewenangan desa, pengelolaan hutan desa dapat termasuk dalam kewenangan lokal berskala desa khususnya di bidang pembangunan desa. Pasal 9 Peraturan Menteri Desa, Pembangunan Daerah Tertinggal, dan Transmigrasi Republik Indonesia Nomer 1 Tahun 2015 Tentang Pedoman Kewenangan Berdasarkan Hak AsalUsul dan Kewenangan Lokal Berskala Desa, menyebutkan kewenangan lokal berskala desa di bidang pembangunan desa meliputi:

a. Pelayanan dasar Desa;

b. Sarana dan pra-sarana Desa;

c. Pengembangan ekonomi lokal Desa; dan

d. Pemanfaatan sumber daya alam dan lingkungan Desa.

Hutan desa merupakan salah satu sumber dayaalam danlingkungandesayang dapat dimanfaatkan untuk kepentingan pembangunan desa. Hal ini selaras dengan tujuan di aturnya pengelolaan hutan desa yaitu untuk memberikan akses kepada desa melalui lembaga desa dalam mengelola sumberdaya hutan secara lestari serta untuk meningkatkan kesejahteraan desa

Pengelolaan hutan yang berada di dekat desa juga dapat merupakan lingkup kewenangan berdasarkan hak asalasul, khususnya dalam hal ini apabila hutan tersebut merupakan hutan yang merupakan hutan adat. Sebagaimana disebutkan dalam Pasal 2 Peraturan Menteri Desa, Pembangunan Daerah Tertinggal, dan Transmigrasi Republik Indonesia Nomer 1 Tahun 2015 Tentang Pedoman Kewenangan Berdasarkan

${ }^{23}$ Redi Ahmad (2014) dalam Subadi dan Rikky Ardianto, "Izin Usaha Pemanfaatan Jasa Lingkungan (IUPJL) Penyerapan atau Penyimpanan Karbon Hutan dalam Perdagangan Karbon Hutan", Yustisia Merdeka, Volume 1, Nomer 2, September 2015, hlm.101. 
Hak Asal-Usul dan Kewenangan Lokal Berskala Desa, menyebutkan bahwa kewenagan berdasarkan hak asal-usul desa diantaranya meliputi : sistem organisasi masyarakat adat, pembinaan lembaga dan hukum adat serta pengelolaan tanah desa atau tanah hak milik desa yang menggunakan sebutan setempat. Adapun ruang lingkup hak asal-usul desa adat sebagaimana disebutkan dalam Pasal 3. antara lain adalah : pranata hukum adat; pemilikan hak tradisional; pengelolaan tanah kas Desa adat; pengelolaan tanah ulayat.

Apabila merujuk pada pengertian hutan desa sebagaimana diatur dalam UU No 41 Tahun 1999 Tentang Kehutanan, maka hutan yang berada di sekitar desa yang merupakan hutan adat pada dasarnya bukan hutan desa dalam pengertian UU Kehutanan. Sebagaimana disebutkan dalam UU No 41 Tahun 1999 Tentang hutan desa merupakan hutan negara adapun hutan adat bukan merupakan hutan negara. Sebagai hutan negara, hutan desa bukan merupakan hutan milik desa. Adapun hutan adat, bukan merupakan hutan negara, melainkan hutan hak.

Berdasarkan UU No 41 tahun 1999 Hutan adat dikatagorikan sebagai hutan negara, namun demikian ketentuan tersebut tidak berlaku lagi pasca Putusan Mahkamah Konstitusi Nomer 35/ PUU-X/2012. Beberapa isi pokok dari putusan Mahkamah Konstitusi tersebut adalah sebagai berikut:

Pertama, pernyataan Mahkamah Konstitusi bahwa UU Kehutanan yang selama ini memasukan hutan adat sebagai bagian dari hutan negara merupakan bentuk dari pengabaian terhadap hak-hak masyarakat adat dan merupakan pelanggaran konstitusi. Mahkamah Konstitusi dalam putusannya menyebutkan: Oleh karena itu, menempatkan hutan adat sebagai bagian dari hutan negara merupakan pengabaian terhadap hak-hak masyarakat hukum adat (Putusan MK 35/PUUX/2012. hal. 173-4). Peryataan bahwa selama ini telah terjadi pengabaian semestinya membuat pemerintah semakin sadar untuk memulihkan hak-hak masyarakat adat yang selama ini "dirampass atau diabaikani.

Kedua, hutan adat dikeluarkan posisinya dari sebelumnya merupakan bagian dari hutan negara kemudian dimasukan sebagai bagian dari kategori hutan hak. Hal ini sebagai konsekuensi dari perubahan Pasal 1 angka 6 UU Kehutanan. $^{24}$

Di dalam Putusan MK No 35 secara tegas disebutkan dengan cetak tebal bahwa hutan adat bukan lagi menjadi bagian dari hutan negara, kategori hutan hak di dalamnya haruslah dimasukkan hutan adat. ${ }^{\text {} 2}$ Lebih lanjut di dalam putusan MK itu disebutkan bahwa posisi hutan adat merupakan bagian dari tanah ulayat masyarakat hukum adat. ${ }^{25}$

"Hutan adat (yang disebut pula hutan marga, hutan pertuanan, atau sebutan lainnya) berada dalam cakupan hak ulayat karena berada dalam satu kesatuan wilayah (ketunggalan wilayah) masyarakathukumadat, yang peragaannya didasarkan atas leluri (traditio) yang hidup dalam suasana rakyat (in de volksfeer) dan mempunyai suatu badan perurusan pusat yang berwibawa dalam seluruh lingkungan wilayahnya." 26

Sebagaimana telah diuraikan sebelumnya, salah satu isu utama berkenaan dengan REDD adalah subyek

24 Yance Arizona, "Peluang hukum implementasi Putusan MK 35 ke dalam konteks kebijakan pengakuan masyarakat adat di Kalimantan Tengah", Makalah disampaikan dalam Lokakarya "Fakta Tekstual Quo Vadis Hutan Adat Pasca Putusan MK No.35/ PUU-X/2012“, Palangkaraya, Rabu 20 November 2013. Acara diselenggarakan oleh AMAN Kalteng dan WWF Program Kalimantan Tengah, hlm. 2.

${ }_{25}$ Ibid.

${ }_{26}$ Putusan MK No. 35/PUU-X/2012, halaman 172-3. 
penerima manfaat, khususnya dalam hal ini adalah kedudukan komunitas lokal/ adat sebagai penerima manfaat. Meskipun telah mulai ada pengakuan terhadap kedudukan komunitas lokal/adat dalam kaitannya dengan pemanfaatan hutan dalam skema REDD, namun belum ada suatu kesepakatan yang jelas dari masyarakat internasional mengenai skema pembagian keuntungan tersebut. Oleh karena itu pembagian keuntungan tersebut akan kembali kepada kebijakan negara masing-masing. Adapun untuk di Indonesia, pembagian keuntungan (distribusibenefit) diatur sebagaiberikut: ${ }^{27}$

\begin{tabular}{|c|c|c|c|}
\hline No & Jenis Hutan & $\begin{array}{l}\text { Pembagian } \\
\text { tungan }\end{array}$ & Keun- \\
\hline \multirow[t]{3}{*}{1} & Hutan Rakyat & Pemerintah & $: 10 \%$ \\
\hline & & Masyarakat & : $70 \%$ \\
\hline & & Pengembang & : $20 \%$ \\
\hline \multirow[t]{3}{*}{2} & Hutan Adat & Pemerintah & $: 10 \%$ \\
\hline & & Masyarakat & : $70 \%$ \\
\hline & & Pengembang & $: 20 \%$ \\
\hline \multirow[t]{2}{*}{3} & Hutan Tana- & $\begin{array}{l}\text { Pemerintah } \\
\text { Masyarakat }\end{array}$ & $\begin{array}{l}: 20 \% \\
: 20 \%\end{array}$ \\
\hline & man & Pengembang & $: 60 \%$ \\
\hline
\end{tabular}

Skema REDD + dalam konteks benefit sharing (pembagian keuntungan) untuk masyarakat hanya nampak dalam distribusi manfaat untuk hutan adat, hutan desa dan hutan rakyat. Namun dalam kenyataannya, sangat sedikit masyarakat yang memiliki akses pada tiga jenis hak ini. Sebagian besar penguasaan mereka atas kawasan hutan berstatus tanpa surat. ${ }^{28}$

\section{SIMPULAN}

Hutan-hutan yang berada di sekitar dan dalam desa dapat dikelola oleh desa dengan berdasarkan kewenangan berdasarkan hak asal-usul dan kewenangan lokal berskala desa. Hutan yang dikelola oleh desa dapat

${ }^{27}$ Permenhut 30/2009 sebagaimana telah diolah oleh Nurtjahjawilayasa,Op.Cit,hlm. 40.

${ }_{28}$ Ibid. berupa hutan desa yang merupakan hutan negara serta hutan adat yang merupakan hutan hak milik. Salah satu bentuk kegiatan pengelolaan hutan oleh desa adalah usaha jasa lingkungan yang meliputi di antaranya adalah kegiatan penyerapan dan atau penyimpanan karbon. Mitigasi perubahan iklim berdasarkan REDD + pada dasarnya berbentuk kegiatan yang memanfaatkan hutan untuk menyimpan dan menyerap karbon guna menekan tingkat emisi gas rumah kaca.

\section{DAFTAR PUSTAKA}

\section{Buku}

Daniel Murdiyarso, 2003, Protokol Kyoto,Implikasinya Bagi Negara Berkembang,Penerbit Buku Kompas, Jakarta, Mei, 2003,

Muhammad Yasin, dkk, 2015, Anotasi Undang-Undang No 6 Tahun 2014 Tentang Desa, Jakarta; PATTIRO.

Peter Mahmud Marzuki, 2005, Metode Penelitian Hukum, Jakarta, Kencana.

\section{Sumber Elektronik (E-Book, E-Jounal, Makalah dan Disertasi)}

Agus Budhi Prasetyo, Serba-Serbi Hutan Desa (HD), hlm. 1, http://bp2sdm. menlhk.go.id/emagazine/Edisi1. pdf, (diakses pada 03/07/2017).

Bernadius Stenni, 2010, "Perubahan Iklim, REDD dan Perdebatan Hak: Dari Bali sampai Kopenhagen, dalam Mumu Muhajir (ed), REDD di Indonesia kemana Akan Melangkah, Studi Tentang Kebijakan Pemerintah dan Kerentanan Masyarakat, Jakarta :HuMa, http://epistema.or.id/ wp-content/uploads/2015/07/ REDD_di_Indonesia.pdf, (diakses pada 03/07/2017).

BPS, Indonesia-Survey Kehutanan 
2014, https://microdata.bps. go.id/mikrodata/index.php/ catalog/723, (12/11/2017).

http://file.upi.edu/Direktori/ F P M I P A / J U R _ P E N D . BIOLOGI/197212031999031WAHYU_SURAKUSUMAH/ Adaptasi_dan_mitigasi.pdf, hlm. 3 (diakses pada 19 maret 2016).

FWI/GFW, 2001, Keadaan Hutan Indonesia, Bogor , Indonesia: Forest Watch Indonesia dan Washington D.C.: Global Forest Watch, hlm.1, https://www. wri.org/sites/default/files/ pdf/indoforest_full_id.pdf, (12/11/2017).

Innesa Destifani, Suwondo, Ike Wanuswamatie, "Pelaksanaan Kewenangan Desa Dalam Rangka MewujudkanOtonomiDesa(Studi pada Desa Sumber, Kecamatan Kradenan, Kabupaten Blora" Jurnal Administrasi Publik (JAP), Vol I, No 6, http://download. portalgaruda.org/article.php?artic le $=190363 \& \mathrm{val}=6469 \&$ title $=\mathrm{P}$ elaksanaan \% 20Kewenangan \% 20 Desa \% 20Dalam \% 20Rangka \% 20 Mewujudkan \% 20Otonomi \% 20 $\mathrm{D}$ e s a \% 20 ( S t u d i \% 20 Pada \% 20Desa \% 20Sumber \% 20Kecamatan \% 20Kradenan \% 20 Kabupaten \% 20Blora), (Diakses pada $03 / 07 / 2016$ ).

International Timber Organization, Tropical Forrest and Climate Change, report of The International Expert Meeting on Addressing Climate Change through Sustainable Management of tropical Forest, Yokohama, Japan, 30 April-2 may 2008, hlm 15, http://redd.unfccc.int/ uploads/2_64_redd_20130206_ itto_tropical_forests_and_ climate_change.pdf, (diakses pada tanggal 03/07/2017).

Kementerian Kehutanan Republik Indonesia, 2008, "Consolidation Report reducing Emission From deforestation and Forest Degrdation In Indonesia", http://www. forestcarbonpartnership.org/ sites/forestcarbonpartnership. org/files/Documents/PDF/IFCA Consolidation_report_REDD_ Indonesia_0.pdf, (diakses pada tanggal 03/07/2017).

Mardisontori, "Membangun dan Memberdayakan Desa Melalui UU Desa" dalam Rechtsvinding, Media Pembinaan Hukum Nasional, Rechtsvinding.bphn. go.id/.../Membangun \% 20 Desa $\% 20$ melalui $\% 20 \ldots$ (12/11/2017).

Mumu Muhajir dan Myrna A Safitri, 2010, "REDD di Indonesia Kebijakan Pemerintah dan Kerentanan Masyarakat" dalam Mumu Muhajir (ed), REDD di Indonesia kemana Akan Melangkah, Studi Tentang Kebijakan Pemerintah dan Kerentanan Masyarakat, Jakarta :HuMa, http:// epistema.or.id/wp-content/ uploads/2015/07/REDD_di_ Indonesia.pdf, (diakses pada 03/07/2017).

Myrna Asnawati Safitri, 2010, Forest Tenure in Indonesia, The Socio Legal Challenges of Securing Communities's Rights, Doctoral Thesis, Faculty of Law, Leiden University, hlm. 49, https://openaccess.leidenuniv. $\mathrm{n} 1 / \mathrm{h}$ a $\mathrm{nd}$ le / $1887 / 16242$ (12/11/2017).

Nurtjahjawilasa, dkk, 2013, Modul Konsep 
REDD + dan Implementasinya, Jakarta :The Nature Conservancy Program Terestrial Indonesia, https://www.nature.or.id/ publikasi/laporan-dan-panduankehutanan/modul-konsep-redd. pdf, (diakses pada 03/07/2017).

Rahmina, 2012, Pilihan Skema Pengelolaan Hutan Berbasis Masyarakat Dalam MItigasi Perubahan Iklim, Jakarta : GIZ dan FORCLIME, http://www.forclime.org/ documents/Books/Buku \% 20 Skema \% 20PBHM \% 20Final.pdf, (diakses pada 12/11/2017).

Subekti Rahayu, dkk, 2016, Pemantauan dan Evaluasi Pengelolaan Hutan Desa Berbasis Masyarakat, Buku Pedoman, Bogor : World Agroforestry Centre (ICRAF), http://www.worldagroforestry. org/downloads/Publications/ PDFS/MN16184.pdf, (diakses pada $07 / 03 / 2017$ )

Subadi dan Rikky Ardianto, "Izin Usaha Pemanfaatan Jasa ingkungan (IUPJL) Penyerapan atau Penyimpanan Karbon Hutan dalam Perdagangan Karbon Hutan", Yustisia Merdeka,Volume 1, Nomer 2, September 2015, www.unmermadiun.ac.id/.../ Jurnal \% 20 Yustisia \% 20 Merdeka/2015/.. (Diakses pada 07/07/2016).

Yance Arizona, "Peluang hukum implementasi Putusan MK 35 ke dalam konteks kebijakan pengakuan masyarakat adat di Kalimantan Tengah", Makalah disampaikan dalam Lokakarya "Fakta Tekstual Quo Vadis Hutan Adat Pasca Putusan MK No.35/PUU-X/2012“, Palangkaraya, Rabu 20 November 2013. Acara diselenggarakan oleh AMAN Kalteng dan WWF Program Kalimantan Tengah, https://anzdoc.com/peluanghukum-implementasi-putusanmk-35-ke-dalam-konteks-... (diakses pada 06/03/2017)

\section{Peraturan Perundang-undangan}

UU No 41 Tahun 1999 Tentang Kehutanan, Lembaran Negara Republik Indonesia Tahun 1999 Nomor 167.

UU No 23 Tahun 2014 Tentang Desa, Lembaran Negara Republik Indonesia Tahun 2014 Nomor 7.

PP No 43 tahun 2014 Tentang Peraturan Pelaksanaan UU No 6 Tahun 2014 Tentang Desa, Lembaran Negara Republik Indonesia Tahun 2014 Nomor 123. 